\title{
Analysis characteristic of corruption in construction project in Indonesia
}

\author{
Felix Hidayat $^{1, *}$, Sherly Mulyanto ${ }^{1}$ \\ ${ }^{1}$ Civil Engineering Department, Faculty of Engineering, Parahyangan Catholic University, 40141 Bandung, Indonesia
}

\begin{abstract}
The competition among providers of construction services often leads corruption. The purpose of this study was to examine the characteristics of corruption in construction projects in Indonesia. The analysis of 15 (fifteen) cases are conducted by grounded theory method using coding techniques. The results showed that (a) the characteristics of construction projects involved in corruption is dominated by projects which, are owned by government that hire private company as the contractor; happen on infrastructure project; located in Java and Sumatra; (b) the vulnerability characteristics of construction projects involved in corruption are: occurs at construction phase due to contractual violation; sequential acts of corruption is begin with the difference between the volume of work that resulted in payments, which is not in accordance with progress reports; and the parties involved is Committing Officer (Pejabat Pembuat Komitmen/PPK); (c) the characteristics of corruption in construction project are: cause losses of $16-33 \%$ of the project value; and prison sentence of 44.8 months with the demands of a fine of USD. 10.660,- (d) the characteristic of the impact of corruption in construction project are: cause construction failure; $73 \%$ had an appeal to the High Court level and 33\% had an appeal to the Supreme Court.
\end{abstract}

\section{Introduction}

Due to the need for construction which continue increase every year, it drives the hard competition among providers of construction services. The competition often leads corruption in Indonesia. According to the Corruption Perception Index 2014 released by Transparency International, Indonesia is ranked 107 th of 175 countries, Singapore is ranked 7th, and Malaysia is ranked 52nd. The number of corruption in Indonesia is still higher compared to other ASEAN countries, such as Singapore and Malaysia.

Corruption occurs repeatedly leave a significant impact both on people and the government. Corruption results in infrastructure development is hampered because of the budget should be utilized for the development are being exploited by some specific parties. Besides corruption also led arises a sense of distrust of the government (Mc Mullan, 1961). In the aspect of its own development, corruption can affect the design and construction has been planned so that the construction can lead to failure.

Corruption is a problem that is often faced by the construction project in Indonesia. Corruption in construction projects that occur repeatedly lead to a pattern of how the corruption occurred. However, the value of the corruption that is large enough with corruption is difficult to be supervised both by society and the government led to corruption in construction projects in Indonesia are still common, especially in government-owned projects. So that's quite interesting if the characteristics of corruption in construction projects in Indonesia to be analyzed. The purpose of this study was to examine the characteristics of corruption in construction projects in Indonesia.

\section{Corruption on construction project}

Characteristics of corruption in construction projects in this study is an extension of previous research on the causal relationship between cause and vulnerability to corruption in the construction sector in China. A causal relationship between cause and vulnerability to corruption in the construction sector in China (Le et al., 2014) can be seen in Figure 1, with parameters that can be seen in Table 1.

Corruption in construction projects that occur repeatedly led to a pattern of corruption. The pattern that eventually developed into the characteristics of corruption in construction projects. Based on previous research on the causal relationship between the causes and vulnerabilities of corruption in the construction sector in China, developed a new pattern of cases of corruption in construction projects, particularly in Indonesia. Vulnerability described in previous studies led to corruption in construction projects in Indonesia. The cases of corruption in construction projects in Indonesia impacts due to corruption in construction projects in Indonesia. So when do the translation of the anatomical form of the structure and mechanisms of corruption in construction projects in Indonesia can be

\footnotetext{
* Corresponding author: hidayat@unpar.ac.id
} 
described with an anatomic characteristics of corruption in construction projects in Indonesia.

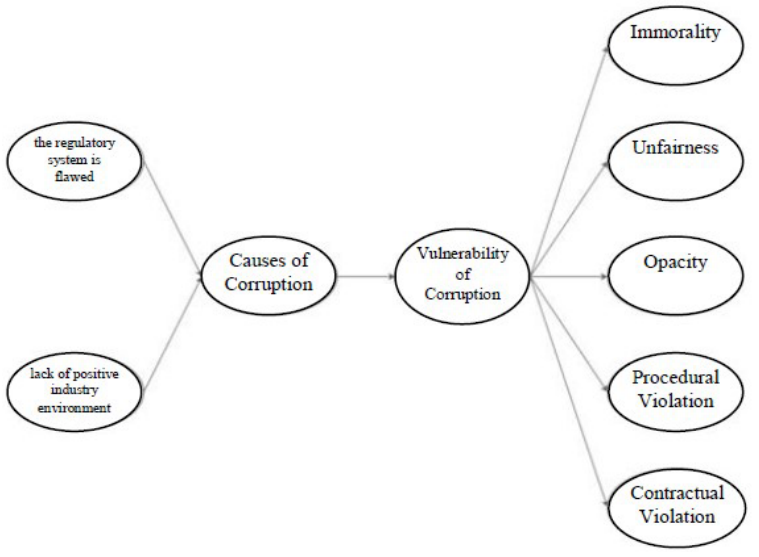

Fig. 1. Causal relationships between causes and susceptibility to corruption in the construction sector in China (Le et al, 2014)

Table 1. Parameter vulnerability to corruption in the construction sector in China (Le et al., 2014)

\begin{tabular}{|c|c|c|}
\hline Construct & Code & Measurement Item \\
\hline \multirow{6}{*}{ Immorality } & IMM1 & The work is not executed as per original design accorded \\
\hline & IMM2 & $\begin{array}{l}\text { Work is executed without the availability of funds for the } \\
\text { said purpose }\end{array}$ \\
\hline & IMM3 & $\begin{array}{l}\text { The changes, especially in abnormally high rated and high } \\
\text { value items are not properly monitored and verified }\end{array}$ \\
\hline & IMM4 & contractors provide false certificate in bidding \\
\hline & IMM5 & Subsitution of unqualified materials in construction \\
\hline & IMM6 & $\begin{array}{l}\text { Site supervisor neglects duties for taking bribe from } \\
\text { contractor }\end{array}$ \\
\hline \multirow{6}{*}{ Unfairness } & UNF1 & $\begin{array}{l}\text { The consultant is not appointed after proper publicity and } \\
\text { open competition }\end{array}$ \\
\hline & UNF2 & $\begin{array}{l}\text { The criteria adopeted in prequalification of consultant are } \\
\text { restrictive and benefit only few consultant }\end{array}$ \\
\hline & UNF3 & The selection of consultant not done by appropriate authority \\
\hline & UNF4 & $\begin{array}{l}\text { The criteria for selection of contractor are rstrictive and } \\
\text { benefit only few contractor }\end{array}$ \\
\hline & UNF5 & $\begin{array}{l}\text { The conditions and spesifications are relaxed in favor of } \\
\text { contractor to whom the work is being awarded }\end{array}$ \\
\hline & UNF6 & $\begin{array}{c}\text { Confidential information of bidding is disclosed to a spesific } \\
\text { bidder }\end{array}$ \\
\hline \multirow{5}{*}{ Opacity } & OPA1 & Adequate and wide publicity is not given to tender \\
\hline & OPA2 & Adequate time for submission of tender or offer not given \\
\hline & $\mathrm{OPA} 3$ & $\begin{array}{l}\text { The evaluation of tenders is not done exactly as per the } \\
\text { notified criteria }\end{array}$ \\
\hline & OPA4 & $\begin{array}{l}\text { The negotiation on tender not done as per laid down } \\
\text { guidelines }\end{array}$ \\
\hline & OPA5 & $\begin{array}{l}\text { A large project should have called for bids split into several } \\
\text { small projects and contracted without bidding }\end{array}$ \\
\hline \multirow{4}{*}{ Procedural Violation } & PRV1 & $\begin{array}{c}\text { Administrative approval and financial sanction not taken to } \\
\text { execute the work }\end{array}$ \\
\hline & PRV2 & Lack of the sanctioned financial provision from the \\
\hline & PRV3 & Work is not executed for the same purpose for which the \\
\hline & PRV4 & The proper record of hindrances is not being maintained \\
\hline \multirow{3}{*}{$\begin{array}{l}\text { Contractual } \\
\text { Violation }\end{array}$} & COV1 & Escalation clause is not applied correctly for admissible \\
\hline & $\mathrm{COV} 2$ & Compliance with conditions regarding deployment of \\
\hline & COV3 & The work order or supply order is not placed with justified \\
\hline
\end{tabular}

Anatomy of the characteristics of corruption in construction projects in Indonesia can be formed by a process system of corruption, which starts from the causes of corruption lead to vulnerability of corruption, then the process of corruption that occurred on the construction project, until the impact of corruption, where the system is influenced by the characteristics of the construction project. Anatomy of the characteristics of corruption in construction projects can be seen in Figure 2.

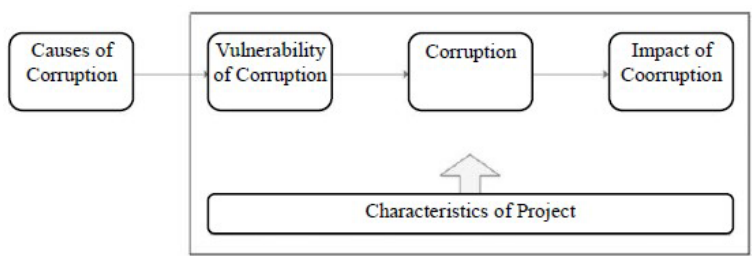

Fig. 2. Characteristics anatomy of corruption in construction projects

\section{Research method}

Data collection techniques used in this research is secondary data. Data used in the form of a Supreme Court ruling against corruption involving construction projects. Source of data used comes from the domain of the Supreme Court, namely www.putusan.mahkamahagung.go.id.

Referring to the characteristics of the data, the research method used is a combination of qualitative and quantitative research methods. Qualitative research methods used in this research is qualitative research with grounded theory approach. The analysis technique used in this research using coding techniques. According Strauss and Corbin, analysis using coding technique is divided into three stages namely open coding, axial coding, and selective coding.

1. At this stage of open coding is done categorization of data based on questions or variables that have been made with a grounded theory approach. In this study, the use of parameters and indicators of previous studies. Parameters and indicators of vulnerability in the form of corruption in construction projects, which in this study was developed back in the vulnerabilities that occur at each stage of construction. If the question explorative discovered new parameters and indicators that did not exist in previous studies, it will be created a new parameter based on the discovery in exploratory questions.

2. The next stage is the stage of axial coding. At this stage the data is new collected after analyzed by open coding. From the collected data obtained four categories that can be analyzed. The categories are vulnerability of corruption in construction projects, corruption in construction projects, the impact of corruption in construction projects, and the characteristics of the construction project. The last stage is the stage of selective coding.

3. Phase selective coding is done by seeking to harmonize between open and selective coding that has been done. So that the parameters will be included in a category that is relevant and of a series of stories. In order to be a story that is consistent, can be made a fishbone diagram. The anatomy of the skeleton to be 
used as a basis for making a fishbone diagram as a result of the analysis in this study.

\section{Data analysis}

\subsection{Characteristics analysis of construction projects}

The 15 cases analyzed was obtained in the form of construction project characteristics of the dominant service provider is private while the dominant service users are the government, the dominant construction project site is Java and Sumatra. The dominant types of construction projects are infrastructure projects, with an average contract value USD. 195.000.000,- (USD. $1=$ Rp. 13.500,-) and the average execution time is 166 days. While the type of tender is most often done is through an auction.

\subsection{Characteristics of vulnerability analysis corruption on construction project}

Vulnerability corruption in the construction project is divided into three stages, namely the pre-construction phase, construction phase and maintenance phase. Vulnerability analysis of corruption in construction projects on coding techniques included in axial coding phase. Of the 15 cases analyzed, sequential most common is the difference in the volume of work that resulted in payments not in accordance with the progress and news reports a fictitious event. It is suspected of corruption in the form of the difference in the volume of work more easily identified if found non-compliance with the contract documents, while another sequential as bribes to get the project could not be found immediately if it does not receive the report. The results of the analysis can be seen in Figure 3. While the majority of the parties involved in corruption in construction projects is the Committing Officer, allegedly because the Commitment Officer is responsible for reports of physical work and payment approval. On the external factors that affect the public intervention seen the construction process so that the implementation of construction projects is not in accordance with applicable regulations and lead to corruption. Of the 15 cases analyzed, the public intervention is more common in construction projects in remote locations and outside Java. This is apparently due to the inland location of indigenous and influence is very strong compared to more modern locations such as in big cities.

\subsection{Analysis on characteristics corruption on construction projects}

Characteristics of corruption in construction projects in the form of loss of value of construction projects involved in corruption and the prosecution of the cases of corruption in construction projects. Analysis of the characteristics of corruption in construction projects in coding techniques included in axial coding phase. Based on sequential corruption in construction projects can be seen that this kind of corruption is most often done is the difference between the volume of work. This means that there is a mismatch between the work done in the field with the work that should be done in the agreement contract. The difference of the volume of work resulting in differences in payments that are not in accordance with the work progress report. The payment difference is the value losses of corruption in construction projects.

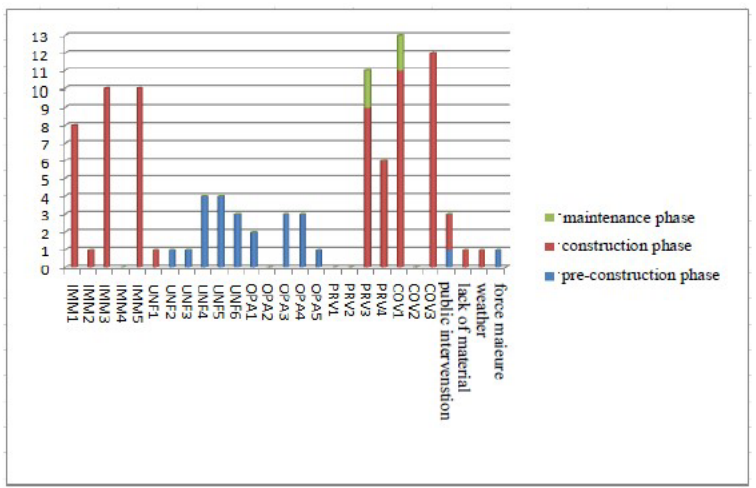

Fig. 3. Corruption vulnerability

Based on 15 cases analyzed, it can be concluded that the difference in the volume of work is a kind of corruption most often occurs in the construction project. Values project losses are in the range of $16.71 \%$ $33.42 \%$ of the contract value of the project. While the demands on the criminal cases of corruption in construction projects had an average demand of 44.8 months imprisonment with the demands of average fine of USD. 10.716.

\subsection{Characteristics analysis on impact corruption construction projects}

The impact of corruption in construction projects can be divided into two, namely the technical and legal implications. On the technical impact is more focused on the effects of corruption in the construction of the building after the maintenance period runs out. While the impact of the law is focused on the decision at the level of district courts, high courts and the supreme court.

Technical impact in the case of corruption in construction projects such as the failure of the construction and the design life of the building is not reached. The impact of construction failure present in 4 cases out of 15 cases analyzed. Construction failure that occurs in the form of collapse of the building, as well as damage to roads. While the impact of the age of the building plan is not achieved only in one case out of 15 cases analyzed. Through this analysis it can be said corruption in construction projects construction prone to failure. The impact of the law in cases of corruption in construction projects is a decision at the level of district courts, high courts and supreme court. Decision against corruption in construction projects can be found guilty or not guilty.

On the characteristics of the impact of corruption in construction projects, it can be concluded that the 
technical impact of the most common is a construction failure. While the impact of the law are most numerous in the district court verdict. A judicial decision can be found guilty or not guilty. Decision of the Supreme Court level, only 1 case was found not guilty, while four other cases convicted. Imprisonment verdict at the Supreme Court level had an average of 33 months with an average fine of USD. 9.260. As for compensation damages ruling by the Supreme Court level there is only one case, which amounted to USD. 15.618,-. Most of the value of money substitutes nominal damages was not mentioned in the decision of the Supreme Court Level. The cases that have not reached the level of the Supreme Court still has the possibility to appeal to the Supreme Court.

\subsection{Summary characteristics corruption construction project}

Characteristics of corruption in construction projects most often occur in the implementation phase of construction with this type of vulnerability is most often done is a vulnerability in the form of contractual violation. Activity corruption is the most frequently performed work orders are not carried out in accordance with applicable regulations. The vulnerabilities that do give rise to corruption in the form of project losses and prosecution of corruption criminal. Based on this analysis, much as $16.71 \%$ to $33.42 \%$ of the nominal value of the project contract losses due to corruption.

The impact of corruption in construction projects in the form of the technical and legal implications. On the technical impact, construction failure is the most common. But of the 15 cases analyzed not all cases are experiencing technical impact. While the impact of the law, all cases have been affected by the law. Legal effect in this study experienced a change rather than the demands put forward in corruption.

Through the analysis of 15 cases of corruption in construction projects, it appears that the impact of the law is not appropriate when compared to the value in corruption. Characteristics of corruption that occur pose a groove pattern or acts of corruption. Based on the analysis in this study sequential corruption in construction projects most often is the difference between the volume of work in the form of changes in the quality and quantity of materials resulted in progress in the field does not correspond to the minutes, so there is a discrepancy between the payment by progress in the field. Sequential dominant corruption can be seen in Figure 4.

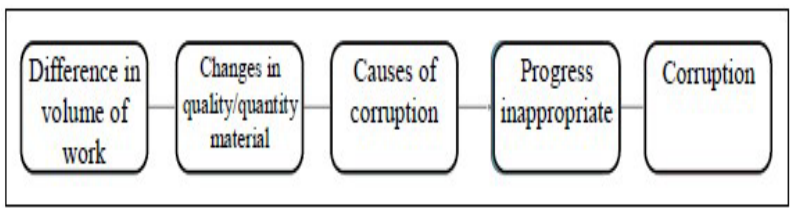

Fig. 4. Sequential corruption in construction projects (dominant)

\section{Conclusion and recommendation}

Based on the analysis performed on the data that has been collected, it can be obtained the following conclusions:

1. On the characteristics of the construction project:

a. Of the 15 cases analyzed, the type of ownership of government service users and the type of ownership of private service providers is a type of ownership that experienced corruption in construction projects.

b. $60 \%$ of the 15 cases analyzed, the type of construction project that involved corruption is an infrastructure project.

c. $53.85 \%$ of the 15 cases analyzed, the project involved the construction of corruption have an average contract value of Rp. USD. 195.000.

2. At vulnerability anatomy of corruption in construction projects:

a. In addition to the parameters and indicators of vulnerabilities that have been there on previous research on the causal relationship between cause and vulnerability to corruption in the construction sector in China (Le et al., 2014), found a new parameter in the form of external factors with indicators of intervention of society, weather, emergencies, and unavailability of materials. In Indonesia, the division of the project site greatly affect the implementation of the project, which at inland locations and customs of the community intervention influence is still very strong compared to the big cities. In addition, limited infrastructure affect the availability of material required in the field.

b. Of the 15 cases analyzed, all cases are susceptible of corruption during the implementation phase of construction. This is apparently due to the implementation phase of construction irregularities committed corruption is easier to detect. Addition of 15 cases analyzed, it was found that the vulnerability in the form of contractual violation be repeated frequently. This is presumably due to vulnerabilities in the form of contractual violation is easier to detect by comparing the execution in the field with the agreed work contracts.

c. Of the 15 cases analyzed it was found that sequential corruption most often occurs is the difference between the volume of work that resulted in payments not in accordance with progress reports with the parties most often involved is the Committing Officer. This is presumably due to the difference in the volume of work more easily identified by comparing the implementation of a contract of employment. In addition, the Commitment Officer is the party most responsible for project progress reports and payment approval of projects based on project progress report.

3 . In the anatomy of corruption in construction projects: a. Of the 15 cases analyzed, it was found construction projects with total losses amounting 
to $16.71 \%$ up to $33.42 \%$ of the most frequently experienced corruption. However, in the area of Nusa Tenggara Islands, and Papua discovered a greater loss value project up to $80 \%$ of the contract value of the project. This is due to the influence of external factors that are large enough in these locations, so that the payment received is not in accordance with the progress that is implemented on the ground.

b. Of the 15 cases analyzed, the demands of imprisonment against corruption in construction projects had an average value during the 44.8 months with the value of the average penalty for USD. 10.716,-. While demand restitution damages only some cases including the same in the Supreme Court ruling. It is suspected that cause corruption in construction projects is often done because of the demands form of imprisonment and fined not comparable with values in corruption.

4. In the anatomy of the impact of corruption in construction projects is $73.33 \%$ of the 15 cases analyzed has reached a verdict in the High Court level and $33.33 \%$ of the 15 cases analyzed has reached a verdict in the Supreme Court.

Suggestions for further research are:

1. Future studies should focus on each type of construction project, in order to take the tendency of corruption in each type of construction project.

2. Future studies should focus on corruption in construction projects by years of corruption in construction projects.

3. Further research should be done further analysis regarding the location of the construction projects involved in corruption in order to know the relationship between the location of construction projects with the trend of corruption.

We would like to express our appreciation to Civil Engineering Department, Faculty of Engineering, Parahyangan Catholic University, for their support and cooperation.

\section{References}

1. Barrie, Donald S. dan Paulson, Bayd C. (1992), Professional construction management: including C. $\mathrm{M}$, Design-construct, and general contracting Ed.3, McGraw-Hill, New York:

2. Bogdan, R.C., dan Biklen, S.K., (1982). Qualitative Research for Education: An Introduction to Theory and Method. Boston, MA: Allyn and Bacon, Inc.

3. Creswell, John W. (2010), Qualitative Inquiry \& Research Design: Choosing Among Five Approaches, London.

4. Grisham, T. (2013). Journal of Construction and Management Engineering, Vol. 5, No. 1, 13-21.

5. Le, Y., Shan, M., Chan, A., and Hu, Y. (2014). Journal of Construction and Management Engineering, Vol. 140, No. 9

6. Le, Y., Shan, M., Chan, A., and Hu, Y. (2014).
Journal of Construction and Management Engineering, Vol. 30, No. 4

7. Strauss, A. L., dan Corbin, J. (1990), Basic of Qualitative Research: Grounded Theory Procedures and Techniques. New Park, CA: Sage. 